\title{
DANSKE RESUMEER
}

\section{Simone Anna Felding \& Nete Schwennesen: Bag skærmen på en digital plat- form. Kunstfærdigt integrationsarbejde og nye samarbejdskonstellationer}

I denne artikel undersøges det manuelle og algoritmiske arbejde, der foregår bag skærmen på en digital platform, som er designet til at afhjælpe og forebygge ensomhed. Platformen udbydes til kommuner af en privat virksomhed og finansieres af kommunerne via et abonnement, som giver kommunens borgere fuld adgang til at oprette sig som brugere og benytte platformen gratis. Baseret på en etnografisk undersøgelse af virksomheden, kommuner og brugere ser vi nærmere på det omfattende og usynlige arbejde, der foregår bag skærmen på Venskabsportalens brugergrænseflade og viser, hvordan dette arbejde artikuleres og mobiliseres manuelt såvel som digitalt via algoritmer. Konkret viser dette arbejde sig gennem et omfattende manuelt og digitalt screeningsarbejde samt onlineog offlinepromoveringen af platformen. Vi viser, hvordan det er en krævende og omfattende proces, som er rettet mod, at brugere er aktive på platformen, at de får svar, at de har tillid til den, samt at kommunerne forbliver tilfredse med samarbejdet. Hermed udfordres forståelsen af platformen som neutral, automatisk og teknisk, og den fremstår i stedet som en skrøbelig anordning af forbindelser mellem mennesker og teknologi, som kontinuerligt skal vedligeholdes for ikke at bryde sammen. Vi viser, hvordan der opstår et paradoksalt forhold til teknologien, når Venskabsportalen på den ene side mobiliserer en forestilling om platformen som en teknologi, der er i stand til at fungere automatisk, og på den anden side må indgå $\mathrm{i}$ et krævende usynligt integrationsarbejde for at få den til at indfri de forventninger, kommunerne har til platformen. Hermed opretholdes forestillingen om teknologien som et teknisk og neutralt værktøj, som på ironisk vis både udgør en forudsætning og en mulig trussel for virksomhedens forretningsmodel. Herudover peger vi på, at der er et tillidsparadoks iboende i platformen, hvor screening og justering af indhold på en og samme tid er afgørende for at opretholde platformen som et trygt rum, hvor brugerne ikke oplever negative reaktioner på deres sårbarhed og åbenhed, men at virksomheden samtidig risikerer at bryde den tillid ved at redigere for meget $\mathrm{i}$ indholdet og hermed blive for synlig over for brugere og kommuner.

Søgeord: privat-offentligt samarbejde, digitale platforme, ensomhed, digital etnografi, digital infrastruktur, kunstfærdigt integrationsarbejde 


\section{Lene Teglhus Kauffmann \& Ulla Skjødt: Livshistorier som grundlag for værdighedsgenererende praksis?}

Artiklen handler om, hvordan livshistorier bidrager til pleje- og omsorgspersonalets praksis med at fremme værdighed for mennesker, der lever med demens på plejecentre. Disse mennesker er ikke længere i stand til at tage vare på sig selv og er dermed afhængige af hjælp døgnet rundt. Vi diskuterer, hvordan livshistorier danner grundlag for at arbejde med værdighed, og ser nærmere på, hvordan arbejdet organiseres omkring dette. På et overordnet niveau iagttager vi livshistorien som en omsorgsteknologi, men vi går i dybden med en undersøgelse af, hvordan livshistorier skaber forskellige tilgange til håndtering af identitet og konstruktion af virkeligheden. Det, man kan kalde livshistorie som tilgang til pleje og omsorg, reflekterer en politisk ambition om at fremme værdighed, og artiklen konkluderer, at det er muligt at nå dette mål, hvis livshistorien anvendes med et fokus på væren og dermed skaber en forbindelse mellem fortid, nutid og fremtid, som tillader en udfoldelse af selvets autenticitet, selv under de svære betingelser, som sygdommen skaber.

Søgeord: livshistorier, demens, identitet, virkelighedskonstruktion, værdighed

\section{Line Steenhold \& Tom Børsen: Fra adfærdsstyrende kontrol til individuel digital mediering. Kritisk teknologiteoretisk analyse af dagpengesystemets digitale ressourcer}

Denne teknoantropologiske artikel analyserer med kritisk teknologiteori ledige a-kassemedlemmers interaktion med dagpengesystemets digitale værktøjer. På baggrund af observationer på jobcentre og a-kasser samt interviews med ledige og jobkonsulenter kortlægger artiklen, hvordan ledige opfatter dagpengesystemets digitale platforme som ukoordinerede, svære at navigere i, unyttige, meningsløse, adfærdsstyrende og kontrollerende. Analysen bidrager til at belyse, hvordan digitale værktøjer påvirker lediges adfærd samt praksis, og den stiller således skarpt på, hvordan digitalisering og adfærd er viklet ind i hinanden. Et felt, hvor det personlige møde forsvinder i effektiviseringen, fordi det digitale erstatter eller overtager det personlige møde. Truslen om økonomiske sanktioner bliver medieret gennem digitale styringsværktøjer, som får ledige til at frygte, at de ikke gør det godt nok, eller at de kommer til at lave fejl. Dette får ledige til at udvikle handlestrategier, der tilfredsstiller systemets krav, men ikke er rettet mod at få et job. Artiklens anden del præsenterer lediges egne forslag til forbedring af de digitale værktøjer. Konkret foreslås de digitale ressourcer redesignet væk fra den kontrolfunktion, de i dag understøtter, til at mediere individuel digital identitet, herunder digital støtte til den enkelte i jobsøgningen. 
Søgeord: ledige, dagpengesystemet i Danmark, Jobnet.dk, teknoantropologi, kritisk teknologiteori, individuel digital mediering

\section{Mia Krogager Mathiasen og Christina Vestergaard: Mini-public som meto- disk eksperiment i studier af fremtidsteknologier og sociale robotter}

Denne artikel udspringer af spørgsmålet om, hvordan man som antropolog kan arbejde med fremtiden som forskningsobjekt, når det, som man ønsker at undersøge, endnu ikke er og derfor ej heller kan observeres med klassiske antropologiske metoder. Artiklens formål er at præsentere mini-public som en alternativ metode til kvalitativ dataindsamling og vidensformidling $i$ antropologisk forskning af fremtidsscenarier. Dette sker ved en beskrivelse af et mini-public-event, der blev afviklet for frivillige repræsentanter fra forskellige samfundsgrupper i Aarhus i efteråret 2018 som led i et større tværfagligt forskningsprojekt på Aarhus Universitet om udviklingen og brugen af sociale robotter.

Søgeord: metodediskussion, fremtidsteknologier, eksperimenterende metoder, sociale robotter, „foreign entanglements“

\section{Sophia Forchhammer Mortensen: Værktøj til fællesskab}

Artiklen omhandler et makerspace i Vancouver, Canada. Gennem empiriske eksempler fra eget feltarbejde i efteråret 2017 udforsker jeg, hvilke betydninger værktøj har for brugere af Vancouver Tool Library. Jeg argumenterer for, at værktøj foruden at være en fysisk teknologi også fremstår som en social teknologi, idet brugerne anvender det til at skabe mening og selverkendelse. Jeg konkluderer, at værktøjet, der lånes i Vancouver Tool Library, bliver tillagt særlig værdi, fordi det har forbindelse til makerspacet, og at dette har indflydelse på, hvordan brugerne forstår det. Værktøjet indgår herigennem i et hverdagspolitisk projekt, som brugerne løbende engagerer sig i gennem deres engagement i makerspacet.

Søgeord: værktøjsbibliotek, makerspace, social teknologi, Nordamerika, adgangsbaseret forbrug

\section{Mads Skovgaard \& Søren Elias Bendixen: Inklusion i det digitale fallesskab}

Med udgangspunkt i et lokalt hackerfællesskab på Manhattan i New York City udforskes i denne artikel de sociale og politiske omstændigheder, der udspiller sig i udviklingen af software til politiske formål. Hackerfællesskabet definerer sig selv som en del af Den Progressive Bevægelse, en venstreorienteret bevægelse, der er inspireret af institutionelt uafhængige og decentraliserede politiske bevægelser 
som Occupy Wall Street, men alligevel arbejder for at få politikere, som de er enige med, valgt ind i etablerede politiske embedspositioner. Hackerfællesskabet mødes for at (videre)udvikle open source-software, der skal bidrage til det progressive politiske projekt. Det er tidligere blevet beskrevet i antropologisk litteratur, hvordan open source-softwarehackerfællesskaber lader sig guide af en bestemt liberalt inspireret hackermoral, men ved Den Politiske Hack Night introduceres ligeledes et progressivt ideal om inklusion som et ledende aspekt $i$ organiseringen. Denne artikel undersøger således, hvad der sker, når hackerfællesskaber opstår i kraft af en venstreorienteret politisk agenda og dermed udformer sig i skæringspunktet mellem hacking af open source-software og progressiv politik. I forlængelse af dette argumenterer artiklen for, at denne form for politisk motiveret hacking kan forstås i lyset af Claude Lévi-Strauss' begreb bricolage, da denne form for hacking forener umiddelbart modsatrettede idealer i et samlet repertoire, der skaber rammerne for den sociale og politiske aktivitet omkring hackerfællesskabet. Vores analyse illustrerer endvidere, hvordan de forskellige politiske og moralske dele af vores informanters repertoire løbende er til forhandling og kontinuerligt udvikles i relation til hinanden inden for rammerne af den eksisterende bricolage.

Søgeord: hacking, politik, progressivisme, inklusion, open source-software, bricolage 